\title{
THE PARADIGM OF SCIENCE INTEGRATION IN ISLAMIC UNIVERSITY: The Historicity and Development Pattern of Islamic Studies in Indonesia
}

\author{
Efrinaldi', Toha Andiko², Taufiqurrahman ${ }^{3}$ \\ ${ }^{1,3}$ State Islamic University (UIN) Imam Bonjol Padang, Indonesia \\ Jl. Sudirman No. 15 Padang, Sumatera Barat \\ E-mail: 1efrinaldi_74@yahoo.co.id/efrinaldi@uinib.ac.id; 3radentaufiq95@gmail.com \\ ${ }^{2}$ State Institute for Islamic Studies (IAIN) Bengkulu, Indonesia \\ Jl. Raden Fatah Pagar Dewa Bengkulu \\ E-mail: toha.andiko@gmail.com
}

\begin{abstract}
This article aims to discuss the patterns of science integration in Islamic universities in Indonesia and the development models. This study used qualitative method, the data source consists of informants and documentation, as well as data collection techniques carried out through in-depth interviews, participant observation, focus group discussions and documentation review. As results, the application of science integration patterns in several Islamic universities turns out to be different, based on different understanding of the concept of science integration and local socio-cultural settings, according to the their respective established backgrounds. The State Islamic University (UIN) generally applies integration, not Islamization, by combining Islamic science and general science. This is stated in the vision and mission of higher education. As for practice, the implementation of science integration is applied to the faculty through direct policy from the university. In general, Islamic universities in Indonesia have already had a philosophical paradigm, by carrying out a distinctive concept of science integration. In the elaboration aspect of the integration paradigm, it is reflected in the applied curriculum. However, from the explanation, science integration actually aims at integrating religious disciplines with modern technology and science, which is implemented in Islamic higher education in Indonesia. In developing the concept of science integration in each UIN in Indonesia, it has editorial diversity and contextual elaboration with the environment and culture of respective regions.
\end{abstract}

Keywords: paradigm; science integration; Islamic studies.

\begin{abstract}
Abstrak: Artikel ini bertujuan membahas pola integrasi keilmuan pada perguruan tinggi Islam di Indonesia dan model pengembangannya. Penelitian ini menggunakan metode kualitatif, sumber datanya terdiri dari informan dan dokumentasi, serta teknik pengumpulan datanya dilakukan melalui wawancara mendalam, observasi partisipasi, focus group discussion dan telaah dokumentasi. Hasilnya, penerapan pola integrasi keilmuan pada beberapa lembaga perguruan tinggi Islam tersebut ternyata berbeda-beda, berdasarkan perbedaan pemahaman tentang konsep integrasi keilmuan dan setting sosial-budaya yang bersifat lokal, sesuai latar belakang perguruan tinggi itu didirikan. Universitas Islam Negeri (UIN) umumnya menerapkan integrasi, bukan islamisasi, yaitu dengan memadukan antara Islamic science dan sains umum. Ini tertuang dalam visi dan misi perguruan tinggi. Adapun prakteknya, pelaksanaan integrasi keilmuan diterapkan pada fakultas melalui kebijakan langsung dari universitas. Secara umum, Perguruan Tinggi Islam di Indonesia telah memiliki paradigma filosofis, dengan mengusung konsep integrasi keilmuan yang khas. Dalam aspek penjabaran paradigma integrasi tersebut, tercermin dalam kurikulum yang diterapkan. Namun, dari penjabarannya integrasi keilmuan sesungguhnya ingin memadukan disiplin ilmu keagamaan dengan teknologi dan sains modern, yang diimplementasikan dalam pendidikan tinggi Islam di Indonesia. Dalam pengembangan konsep integrasi keilmuan di masing-masing UIN di Indonesia memiliki keragaman redaksional dan elaborasi yang sangat kontekstual dengan lingkungan dan kultur daerah masing-masing.
\end{abstract}

Kata kunci: paradigm; integrasi keilmuan; kajian keislaman.

\section{Introduction}

In the development of Islamic universities in Indonesia nowadays, the paradigm of science integration becomes an essential discourse, especially for every State Institute for Islamic Studies (IAIN) transformed into State Islamic Universities (UIN). The issue of actual science integration in the scientific realm is always an 
actual study in the academy. Since the Islamization of the knowledge of science by Ismail Raji 'alFaruqi in the decade of the $80 \mathrm{~s}$, to the formation of Islamic higher education institutions based on knowledge integration through the transition of IAIN and UIN status in Indonesia in the era of the 2000s until now, as well as a number of dynamics of change model of Islamic education in the Southeast Asia.

In the dynamics of developing Islamic higher education in Indonesia, it seems that the IAIN has transformed and must reform it thoroughly, in terms of infrastructure, superstructure, and new scientific design dimensions. Related to the new scientific design dimensions, we must revise the science that has been developed, as it has been done by the State Islamic University (UIN) Syarif Hidayatullah, the State Islamic University (UIN) Sunan Kalijaga and so forth in Indonesia which have already changed the institution status. However, the fact of this status shift still raises intriguing questions. In what direction is the IAIN science paradigm after switching status? What kind of revision will be created from this phenomenon? Will the main characteristics of IAIN as an Islamic higher institution disappear and become an ordinary (secular) public universities by changing its status to UIN? What is the function of the word 'Islam' in the abbreviation of the UIN? Or is this change in status merely a millennial euphoria that has been responded to halfheartedly? and many more questions. From this aspect, this research is part of an academic responsibility form that seeks to find answers to epistemological problems that arise due to the transition of IAIN status to UIN, by exploring the experience of a number of universities in Indonesia in implementing science integration.

As seen from the background above, there is a tendency for science integration between Islamic and general studies in Islamic higher education in a number of regions. Therefore, this article will discuss how the pattern of science integration in the context of developing Islamic studies in Islamic higher education institutions in Indonesia.

\section{Method}

This study used a qualitative method. The data source consists of informants who understand the data of this study and documentation. Data collection techniques were carried out through indepth interviews, participatory observation, focus group discussions and documentation review. Through interviews, it is also known a variety of things hidden on the subject of research. ${ }^{1}$ In addition to interviews, observation is also used with the aim of being able to understand well and bring researchers to in-depth experiences about the object. ${ }^{2}$ Focus Group Discussion (FGD) is also used to find the meaning of a theme according to the understanding of a group, so that researchers can avoid fallacy. This technique is used to draw the conclusions about difficult meanings and avoid the subjectivity of researchers. ${ }^{3} \mathrm{~A}$ document review is then conducted to support and to accomplish the information.

\section{The Science Integration Models}

The word integration etymologically comes from English, which means unification and integration. In lexicographic analysis, the science integration is the unification of separated sciences. The integration of science can also be interpreted as a union between the religious and general sciences. ${ }^{4}$ This merging effort was made to melt the polarization between the religious and general sciences and their polarization as an independent source of truth. ${ }^{5}$ This concept is developed at the State Islamic University (UIN) in Indonesia which substantially refers to the same estuary, namely the elimination of the dichotomy between the truth of revelation and the truth of modern science. In other words,

\footnotetext{
${ }^{1}$ Lexi J. Moloang, Metode Penelitian Kualitatif, (Bandung: Rosdakarya, 1988), p. 34.

${ }^{2}$ Lexi J. Moloang, Metode Penelitian..., p.. 42.

3 Burhan Bungin, Analisis Data Penelitian kualitatif, (Jakarta: Raja Grafindo Persada, 2003), p. 131.

4 Nurlena Rifai, et.al, "Integrasi Keilmuan dalam Membangun Kurikulum di UIN Se-Indonesia: Evaluasi Penerapan Integrasi Keilmuan dalam Kurikulum dan Proses Pembelajaran", Jurnal Tarbiya, vol. 1, no. 1, (Juni 1, 2014), p. 27. Pius A. Partanto dan M. Dahlan al-Barry, Kamus Ilmiah Populer (Surabaya: Arkola, 1994), p. 264.

${ }_{5}$ Nurlena Rifai, et.al., "Integrasi Keilmuan..., p. 27. Alim Roswantoro in M. Yusuf and Mustofa (ed.), Mengukir Prestasi di Jalur Khusus (Yogyakarta: Depag RI, 2007), p. 40.
} 
science integration is able to combine the truth of revelation with the truth of science implemented in the education process. However, the concept of science integration in each UIN in Indonesia has editorial diversity and elaboration that is very contextual with their respective environments.

In developing the Islamic education system in Indonesia, science integration has become a paradigm that is very relevant to the needs of the times. Science integration is expected to be able to answer the impasse in Islamic scholarship and to answer the complexity of humanitarian problems in the globalization era. However, this paradigm is not easy to apply in hacking the dichotomy of science and development of Islamic higher education, and even creates a lot of confusion, especially for certain study programs.

The most difficult problem to do in an effort to integrate Islamic studies is how to formulate the methodology. The integration effort mostly done now is the unification of study material from Islamic studies in the study of general sciences or vice versa, such as integrating Islamic study material, especially the Quran and Hadith with the study of general sciences in various perspectives.

The discourse around the distinction of science paradigms between Islamic and general sciences at the epistemological level has long been a subject of discussion among Muslim intellectuals. In the modern era, at least two models of science integration ideas emerged. The first model is the Islamization of science carried by two Muslim intellectuals, Ismail Raji al-Faruqi (d. 1986) ${ }^{6}$ and Syed Naquib al-Attas. Ismail Raji al-Faruqi noticed the need for a radical effort to reform the paradigm of science in the Islamic world. Through his book, the Islamization of knowledge, he put forward the idea of the union of Islamic sciences with general sciences, which so far have been regarded as two different things. Al-Faruqi, and also supported by al-Attas explained, that modern science in the world of education based on empirical facts is proven to have weaknesses from various sides, or even Muhammad Iqbal stated it as something evil,

${ }^{6}$ Ramayulis and Samsul Nizar, Ensiklopedi Tokoh Pendidikan Islam, Mengenal Tokoh Pendidikan Islam di Dunia Islam dan di Indonesia (Ciputat, Quantum Teaching: 2005), p. 107. because it neglects aspects of mental, moral and the spiritual development of the younger generation. As a result, a moral and character crisis engulfed the young generation. ${ }^{7}$

Therefore, it is necessary to accommodate the moral aspects, in this case Islamic norms, in all the developed science systems. The essence of Islamic knowledge and culture is Islam. While the essence of Islam is monotheism. Monotheism is the main principle in determining the style of culture and science. Trust in oneness (monotheism) and the sovereignty of God is the foundation of the social and moral system carried by the Messenger of Allah. That belief (monotheism) is the only starting point of philosophy, politics, and culture in Islam. ${ }^{8}$

Monotheism can form the identity of Islamic civilization, which binds all its elements and makes these elements as an integral and organic unity, by forming science and culture within the frame of monotheism. It creates the elements of science and culture to be harmonious and supportive. ${ }^{9}$ There are five main objectives of the Islamization of science initiated by al-Faruqi, namely: 1) mastering the discipline of modern sciences; 2) mastering Islamic treasures; 3 ) determining the specific relevance of Islam in each branch of modern knowledge; 4) finding ways to do creative synthesis between the Islamic treasures and modern science; 5) directing Islamic thought to trajectories that lead to the fulfillment of Allah SWT's design patterns. ${ }^{10}$ These five goals will create to the Islamization of science by bringing together the treasures of modern science within the framework and frame of Islam.

${ }^{7}$ Abu al-Hasan Ali al-Husni al-Nadwi, Percikan Kegeniusan Dr. Muhammad lqbal (Jakarta: Integrita Press, 1985), p. 51.

8 Efrinaldi, "Spektrum Fiqh Siyasah dan Dinamisasi Pemikiran Politik Islam di Indonesia, Madania: Jurnal Madania, vol. XVII, No. I, (Juni 2013), p. 22.

9 Ismail Raji al-Faruqi, Al-Tauhid: Its Implications for Thought and Life. Virginia-USA: The International Institute of Islamic Thought, 1992, p.19-21, See. Also, Tauhid (Bandung, Pustaka, 1988), p. 16-17

${ }^{10}$ In al-Faruqi's view, 12 technical steps to address this were explained, including: conducting a survey of scientific disciplines, pouring back modern disciplines into the Islamic framework with the output of books from higher education levels, and disseminating knowledge that had already been Islamized. See Ismail Raji al-Faruqi, Islamisasi Pengetahuan, transl. Anas Mahyuddin, (Bandung, Pustaka, 1984), p. 2-7. 
The second model is the idea put forward by Ziauddin Sardar." In his perspectives, Islam does not require to be relevant with modern science. In fact, modern science must be relevant with Islam. The position of Islam must be prioritized, the principle of its truth is eternal because it is sourced from revelation. He criticized al-Faruqi's way of thinking which he said only exploited Islamic science, but still used the Western style of thinking. Therefore, he proposed the need to build an Islamic world view on how to build an Islamic epistemology based on the Quran and Hadith and understand the development of the contemporary world. Islamic epistemology cannot be built by relying on existing scientific disciplines, but must begin by developing a new paradigm where the external expressions of Islamic civilization which include science, technology, politics, relations between nations, and the development of national societies, can be studied and developed to human practical needs according to contemporary reality.

However, both models of science integration have been tried to be developed by a number of universities, both at national and international levels. Therefore it should be pursued a mapping of the models that have been developed, especially regarding how the application of the paradigm of science integration in the development of Islamic studies at the university level.

\section{The Science Integration in Islamic Higher Education}

In the Indonesian context, scientific development in Islamic educational institutions has been applied with a number of integration models along with the transition of status of some IAINs to UIN. The pattern and model of integration-interconnection developed by $M$. Amin Abdullah at UIN Sunan Kalijaga Jogyakarta, for example, includes informative, confirmative and corrective. While alternative integrationinterconnection models are parallelization,

${ }^{11}$ Ziauddin Sardar's expertise and figure was known as an intellectual born in Pakistan in 1951. He was a critical figure, his thoughts encompassed a variety of scientific discourse ranging from Islamic studies, scientific policy, literature, and philosophy. similarization, complementation, comparison, inductification and verification. ${ }^{12}$ The application of the integration-interconnection model is a positive step in the context of developing a wider range of Islamic study areas. Each the scientific sector is aware of the inherent deficiencies, and therefore willing to dialogue, to cooperate and to utilize the methods and approaches used by other scientific groups to complement the deficiencies. ${ }^{13}$

The application of science integration in the development of Islamic studies is also carried out at Islamic higher education in Malaysia, Brunei Darussalam and Pattani, Thailand. The model developed by the International Islamic University of Malaysia, for example, when it was founded on May 20, 1983 emphasized an important effort in the integration of Islamic scholarship by integrating Islamic science with humanity. Malaysian scientists united to revive the scientific tradition based on the teachings of the holy Quran and the developed science inseparable from the basic principles of Islam. The science integration model applied by the International Islamic University Malaysia (IIUM), actually IIUM strengthens it with the term Islamization of science, encourages the use of Islamic values and teachings in scientific research activities, promotes scientific studies and makes the Quran as a source of inspiration and reference activities scientific activities. Furthermore, the application of science integration at the Islamic Education Institution supports the aspiration to restore Arabic as the language of science throughout the Islamic World and unite Muslim scientists to advance the Islamic community in the fields of science and technology. ${ }^{14}$ The application of science integration is also carried out in Brunei Darussalam, and one of the universities in the country which is actively developing integration models is the University of Brunei Darussalam.

${ }^{12}$ M. Amin Abdullah, Islamic Studies di Perguruan Tinggi: Paradigma Integratif-Interkonektif, (Yogyakarta: Pustaka Pelajar, 2006), p. 407.

${ }^{13}$ M. Amin Abdullah, Islamic Studies..., p. 408.

${ }^{14}$ Wan Ramli bin Wan Daud dan Shaharir, "Pemelayuan, Pemalaysiaan dan Pengislaman Ilmu Sains dan Teknologi dalam Konteks Dasar Sains Negara", Jurnal Kesturi, no. 1. (1999), p. 15-16. 
Likewise, the College of Islamic Studies Pattani Thailand.

Since the transition of IAIN status to UIN first occurred in Indonesia, beginning with the change in status of IAIN Syarif Hidayatullah Jakarta to UIN Syarif Hidayatullah Jakarta in 2002 and until now, it turns out that the tendency toward the secularization of science seems to be getting stronger, which is marked by a decrease in interest drastically against the Islamic sciences at UIN at religious faculties that have existed before.

However, this does not mean that the integration pattern has not yet begun in Indonesia. One of the pilot icons in the application of science integration in the IAIN and UIN environment in Indonesia, UIN Sunan Kalijaga has built and implemented an integrative model, termed interconnection and science integration. When compared with the scientific building that developed at UIN Syarif Hidayatullah Jakarta through its central figure Harun Nasution, then Islamic studies are still limited to religious studies (figh oriented). The study and teaching of philosophy and tasauf are also still limited to the thinking of certain figures. Likewise, the study and teaching of history, also still relies on political history which is based on the classical literature of Islamic history, not much utilizing the perspective of the social sciences. Therefore, Harun proposed a core guideline with which the guideline can study Islam comprehensively, with his book Islam in terms of its various aspects. This book is then used as a reference throughout the IAIN in the context of a comprehensive introduction to Islam. At least, Harun's steps have made the first step towards science integration efforts at IAIN, even though Harun's thoughts at that time were considered unusual and caused a prolonged controversy. For some people, Harun's views in this matter are incompatible with the mainstream Islamic scholarship and too biased Western concepts. ${ }^{15}$

The influence of the Islamization of science promoted by Naquib al-Attas and Ismail al-Faruqi

${ }^{15}$ Fuad Jabali and Jamhari, IAIN dan Modernisasi Islam di Indonesia, (Jakarta: Logos Wacana IImu, 2002), p. 42-43. also occured in Indonesia, this was demonstrated by the emergence of figures who had serious attention to efforts to resolve the dichotomy of science, such as Kontowijoyo, Amin Abdullah and others. Even though the concept and paradigm are not the same, but the influence has been increasingly felt since the status of the State Institute of Islamic Studies (IAIN) became a State Islamic University (UIN) since 2002. ${ }^{16}$ One of the factors driving the change of IAIN to UIN as mentioned by Abuddin Nata is to resolve the dichotomy of the religious and general sciences. The solution of this dichotomy problem is the integration program of science between religious and general science. Assuming that if IAIN only organized religious sciences, it would continue to preserve the dichotomy. Therefore, IAIN must become UIN to be able to establish general faculties. ${ }^{17}$

In line with the opinion of Abuddin Nata, the concept and paradigm offered by several State Islamic Universities (UIN) in Indonesia to resolve the dichotomy of religious and general science is integration. This concept was developed at the State Islamic University (UIN) in Indonesia which substantially actually refers to the same goal, namely the elimination of the dichotomy between the truth of revelation and the modern science. In other words, science integration eagers to combine the truth of revelation with the truth of science that implemented in the education process. However, the concept of science integration in each UIN in Indonesia has editorial diversity and elaboration that is very

${ }^{16}$ Since 2002 to now, the 17 IAIN campuses have been transformed into UIN throughout Indonesia, namely UIN Syarif Hidayatullah Jakarta, UIN Sunan Gunung Djati Bandung, UIN Sunan Kalijaga Yogyakarta, UIN Alauddin Makassar, UIN Syarif Kasim Riau, UIN Maulana Malik Ibrahim Malang, North Sumatra UIN, Walisongo Semarang UIN, Ar-Raniry Aceh UIN, Raden Fatah Palembang UIN, Sunan Ampel Surabaya UIN, Imam Bonjol Padang UIN, Antasari Banjarmasin UIN, Sultan Thaha Saifuddin Jambi UIN, Raden Intan Lampung UIN, Sultan Maulana Hasanuddin UIN Banten.

17 Abuddin Nata explained that there are five reasons why IAIN has to change into UIN, namely changing the type of education, solutions to the dichotomy of knowledge, opening up greater employment opportunities, opening up opportunities for vertical mobility and demands for professional education. Abuddin Nata, Manajemen Pendidikan, (Jakarta: Kencana Prenada Media Group, 2010), p. 56-65. 
contextual with their respective environments. ${ }^{18}$

UIN Syarif Hidayatullah carries a science paradigm which explains that Islam does not recognize the dichotomy of science, because the source of all science is from Allah SWT. Therefore, the science paradigm developed is an attempt to bring science together with the truth of revelation. Related to the concept of integrase, UIN Syarif Hidayatullah interprets it with a combination of internal religion and science, as well as integration between religious and general science. This combination includes three aspects or levels, namely; ontological, classified science, and methodological integration. ${ }^{19}$

UIN Sunan Gunung Djati Bandung developed a science paradigm which states that religion and science have developed along with the dynamics of science and human thought. Science is not only from deep reasoning towards the objects of science contained in God's material creation, but also more importantly God himself as the basic source of all science. The combination of kauniyyah and qur'aniyyah verses will create a science paradigm based on revelation and rationality. The concept of science integration developed is the integration of science following the philosophy of the wheel which has three components, namely the axle, the spokes (wheels) and tire. The three components work simultaneously in accordance with their respective functions. Thus, the science integration is the integration of quraniyyah and kauniyyah verses that include ontological, epistemological, and axiological aspects. ${ }^{20}$

Then UIN Sunan Kalijaga promoted science paradigms related to the existence of Islam to develop a science that is universal and does not recognize the dichotomy between the sciences of qauliyyah / hadharah al-nash (the sciences relating to religious texts) with the sciences of kauniyyah ijtima'iyah / hadharah al-ilm (natural and social sciences), as well as hadhârah al-falsafah (ethicalphilosophical sciences). The concept of advanced integration is integration-interconnection which is a building of universal science that never

\footnotetext{
${ }^{18}$ Nurlena Rifai, et.al., "Integrasi Keilmuan..., p. 27.

${ }^{19}$ Nurlena Rifai, et.al., “Integrasi Keilmuan..., p. 28.

${ }^{20}$ Nurlena Rifai, et.al, “Integrasi Keilmuan..., p. 28
}

separates between the realm of religion and modern science. Therefore, science integration is the integration of hadharah al-nash, hadhârah al-ilm, and hadharah al-falsafah carried out through 2 models, namely; (1) integration-interconnection in the internal area of Islamic sciences, and (2) integration-interconnection of Islamic sciences with general sciences. ${ }^{21}$

Unfortunately from the six State Islamic Universities (UIN) emerged in the early period that carried the ideals of science integration, it seems that only two UINs have definitively formulated the concept of science integration and socialize it to the academic community, namely the State Islamic University (UIN) Sunan Kalijaga Yogyakarta and the State Islamic University (UIN) Maulana Malik Ibrahim Malang. ${ }^{22}$

\section{Epistemological Discourse on Development of Science Integration Paradigm}

According to Islamic perspective, the study of science is basically a means for humans to lead their main tasks. Thus, science must be integrated in the tasks of human beings as caliphs and servants of Allah SWT, which includes the introduction of scientific areas, emphasis on understanding the potentials of humans and their applications dynamically, concentration in planning and evaluating results, meaning in all their activities and the existence of a positive relationship arrangement with all parties related to the implementation of the task. ${ }^{23}$

The discussion about science integration is inseparable from the development of the growing epistemological discourse of science, emerging and developing in the Islamic and Western perspectives. Epistemology in general is known as theory of science, a branch of philosophy that studies the basics and limits of science. ${ }^{24}$ According to another definition, it is a branch of philosophy regarding the source, structure,

\footnotetext{
${ }^{21}$ Nurlena Rifai, et.al “Integrasi Keilmuan..., p. 29

${ }^{22}$ Nurlena Rifai, et.al “Integrasi Keilmuan..., p. 29

23 Machasin, "Integrasi Ilmu-Ilmu Keislaman: Sebuah Catatan Kecil", The paper was presented on Integrative Knowledge Design Workshop in Islamic Universities at UIN Sunan Kalijaga Yogyakarta, Mei 9, 2004, p. 372.

${ }^{24} \mathrm{KBBI}$ Online, https://kbbi.web.id/epistemologi, accessed on March 27, 2020.
} 
method, and validity of a science. ${ }^{25}$ The term epistemology was first used by James Frederick Ferrier (1808-1864), a British philosopher, in 1854. However the framework of thinking in that direction can be traced in Plato's thought. The main problems in epistemology, as revealed by Harold $\mathrm{H}$. Titus, are: 1 ). what is the source of science? where does true science come from and how do you know it? 2). what is the character of science? 3). Is that science something true? And how to distinguish between right and wrong? ${ }^{26}$ In this discussion, we will explain the basic forms, developments and epistemological limits of science, both in Islamic and Western perspective.

Modern and religious science both basically offer alternative interpretations. The fundamental difference lies in the search for truth, or what is called epistemology. Interpretations of modern science rely more on causality, while interpretations of religious sciences rely more on meaning. Despite having fundamental differences in its logic format, both are rational and have the same opportunity to develop themselves through the ages. In their experiences, they both use theoretical paradigms. ${ }^{27}$

Various challenges and collisions began to occur when the Western world holds the hegemony and supremacy of world science and civilization. In line with the progress of the West, the Islamic side is experiencing a variety of rumors and anxiety of thought, so that the idea of integration of science emerged. Before this concept was truly "booming" in various parts of the Islamic world, the paradigm of the Islamization of science was put forward by Muslim scholars. The Islamization of science is not a new perspective in the development of Islamic studies, but the spirit has emerged since the beginning of Islam. The Prophet Muhammad SAW had carried out the Islamization of the science and civilization of Jahiliyah. The Islamization when it was done by the Prophets by adjusting the science and

${ }^{25}$ Epistemologi from Greek means episteme (knowledge) and logos (theory). See. Anton Baker, et.al, Metodologi Penelitian Filsafat, (Yogyakarta: Kanisius, 1990), p. 25.

26 Harold H. Titus et.al, Persoalan-Persoalan Filsafat, (Jakarta: Bulan Bintang, 1984), p. 188.

${ }^{27}$ Holmes Rolston, Science and Religion, a Critical Survey, (Newyork: Random House, 1987), p. 1. norms of Jahiliyan's life with Islamic law. For approximately 23 years, the Islamization carried out by the Prophets then became a guide also for the friends and leaders of the next Muslim world in developing Islamic studies. ${ }^{28}$

During the reign of the Abbasid Daula, the caliphs who ruled and were fond of science carried out Islamization with the translation of classical Greek philosophical books into Arabic. Philosophical studies were rigorously selected and certain sections are discarded because they were not in line with Islamic teachings. The inception of great figures and thinkers in Islam in the classical century was the result of the Islamization of science carried out by the caliphs. Therefore, Islamic figures and thinkers such as al-Farabi, al-Razi, Ibn Sina and others could be called as the products of the Islamization of science. ${ }^{29}$

Islamization as a paradigm was re-popularized in modern era, especially after the dichotomy and conflict between Islamic and secular sciences. Secular sciences developed in the Western world creating rationalism, empiricism and secularism are seen by some Muslim scientists as a separate challenge in the life of Islamic society in modern era. On the one hand, secular sciences originating from the Western world have brought benefits to people's lives. On the other hand they can obscure the essence of science and religious moral values. The value-free and neutral science glorified by Western writers could possibly destroy the joints of religion and science in Islam.

The challenges that emanate from Western secular sciences have received dominant attention from thinkers in the Muslim world. Naquib alAttas, ${ }^{30}$ for example among Islamic thinkers who paid serious attention to the development of secular sciences, and their influence on the lives of Muslims. Through the paradigm of the Islamization of science, al-Attas began to create a new epistemological framework in building Islamic science and civilization. The Islamization of

${ }^{28}$ Ahmad Syalabi, Sejarah dan Perdaban Islam, (Jakarta: Pustaka al-Husna Zikra, 2007).

29 M. Atiqul Haque, Seratus Pahlawan Muslim yang Mengubah Dunia, (Yogyakarta: Diglossia, 2007), p. 273.

3o Wan Mohammadd Nor Wan Daud, The Educational Philosophy And Practice of Sayed Muhammad Naquib al-Attas, (Kuala Lumpur: ISTAC, 1998), p. 1-2. 
science into al-Attas's offer around the 1970s was based on the sharp distinction between Islamic and secular sciences which are easily found on the spectrum of anthology and epistemology of science. Before Naquib al-Attas, there were actually many Muslim scholars who paid attention to the Islamization of science, for example Muhammad Iqbal ${ }^{31}$ and Sayyed Husein Nasr. ${ }^{32}$ Even though the proclaimed idea of islamization of science was not yet concorded by the concepts and systematics promoted by al-Attas, at least they already had serious attention to the problems of science and civilization encountered by Islam.

The idea of the Islamization of science was first raised by al-Attas in 1977 at a world conference held in Mecca at the initiative of King Abdul Aziz University. The conference succeeded in gathering as many as 150 papers from 40 Muslim countries in the world. One of them was Naquib al-Attas's paper entitled "Preliminary Thoughts on the Nature of Knowlwdge and the Definition and the Aims of Education". Al-Attas discussed the Islamization of science to overcome the conflict between value-free modern science and Islamic sciences. Ismail R. al-Faruqi also presented a paper entitled "Islamicizing Social Science." 33

Islamization as mentioned by al-Attas is human liberation from superstition, mythology and anismism. Islamization is also the liberation of human reason from the shackles of secularism that the Western world intentionally blows on. The Islamization of science is not related to the process of evolution, but rather the return to natural aspects (fitrah). Therefore, the construction of Western science must be changed and adjusted back to the spirit of Islam in the development of science and civilization in Muslim

${ }^{31}$ Muhammad Iqbal lahir di Punjab, India pada tanggal 9 November 1876. Saleh Nur "Muhammad Iqbal: Studi Pemikiran Filsafat dan Tasawuf”, Jurnal Ushuluddin, vol. XV no. 2 (Juli 2009), p. 228.

${ }^{32}$ Seyyed Hossein Nasr was born in Teheran, on April $7^{\text {th }}$ 1993. Sayyed Hossein Nasr, Islam and the Plight Modern Man, (London: Longmans, 1976), p. 79.

${ }^{33}$ Muhaimin, Arah Baru Pengembangan Pendidikan Islam; Pemberdayaan, Pengembangan Kurikulum, hingga Redefinisi Islamisasi Pengetahuan, (Bandung: Penerbit Nuansa, 2003), p. 31-32. societies. ${ }^{34}$ Besides al-Attas, the Muslim scholar who gave serious attention to the Islamization of science was Ismail al-Faruqi around the 1980s. 35 This Palestine Muslim scholar mentioned that the concepts, theories and methodologies of science developed in the Western world were not in line with the ecology and social systems of Islamic societies. In many cases, the use of Western concepts, theories and methodologies caused various collisions and challenges in the life of Islamic society. The way out of these problems according to Ismail al-Faruqi was to synergize and to integrate concepts, theories, and methodologies originating from the Western world with the spirit of Islamic ethics. Therefore, the Islamization of science according to Isamil al-Faruqi is to redefine and to rearrange modern science built by the Western world and then given a basis and purpose in accordance with Islamic teachings. ${ }^{36}$

Therefore, each Southeast Asian country that has a Muslim population responds to the offer of islamization of science advanced by al-Attas and al-Faruqi in various forms. In Malaysia, for example, several universities that have secular science and Islamic study programs tend to use the terms Islamization and integration, without providing strict boundaries for each concept. The same thing is also found in various universities in the country of Thailand and Brunei Darussalam. ${ }^{37}$

Furthermore, there are 3 (three) science epistemological traditions in Islam, as a theory of science in Islam to achieve truth, namely: First, the epistemology of bayâni, ${ }^{38}$ a way of thinking that makes the text (the Quran and Hadith) an authoritative source of ready-made

34 Ismail Thoib dan Mukhlis "Dari Islamisasi Ilmu Hingga Pengilmuan Islam: Melawan Hegemoni Epistemologi Barat”, Jurnal Studi Keislaman, vol. 17, no. 1 (Juni 2013), p. 66.

35 Ramayulis dan Syamsul Nizar, Ensiklopedi Tokoh Pendidikan Islam, Mengenal Tokoh Pendidikan Islam di Dunia Islam dan di Indonesia, (Ciputat: Quantum Teaching, 2005), p. 107.

${ }^{36}$ Ramayulis dan Syamsul Nizar, Ensiklopedi Tokoh..., p. 77-78.

${ }^{37}$ Dato' Jamil Usman, Wawancara di IIUM, August 8, 2017.

${ }^{38}$ Bayani in Arabic means explanation. Ibn al-Manzhur in Lisan al-'Arab mentioned that the word 'bayan' contains several meanings, which are relevant in this study including al-fashlu wa al-infishal (separating and separated) and al-zhuhur wa alizhar (clear or clarification), see Ibn al-Manzhur, Lisan al-'Arab (Beirut: Dar al-Kutub, t.th), p. 76-78. 
science. This model emphasizes the validity of text transmission from generation to generation. Whether the transmission of the text really determines the correctness of the stipulated legal provisions, this is seen in the science of hadith, especially concerning sanad, rawi and matan. The text consists of lafaz and meaning. In order to gain science from lafaz and meaning, the bayâni method takes two ways: first, holding on to the editor of the text (lafaz), using Arabic rules such as nahwu and sharaf. Second, holding on to the meaning of the text by using logic, reasoning as a means of analysis.

Second, the epistemology of irfani, a way of thinking based on kasyf, the disclosure of the secret of reality by God, which is oriented to the expression of meaning or inner dimensions. In this case, the irfani method uses two ways to obtain it, namely: first, by i'tibar or qiyas irfani, namely the meaning of zahir in the text is captured in kasyf as an inner analogy; then second, with syatahât, which is an oral expression of feelings (al-wijdân) because of the abundance of science directly from the source and accompanied by recognition. Syatahât is irregular and out of place. Science of this model is obtained by spiritual cultivation, purification of the soul and heart, so that God is pleased to transfer science directly to him. To obtain this science, it is necessary to go through several stages or spiritual stations like those of the salik in the tasauf perspectives.

Third, Burhani epistemology, the way of thinking which is based on the power of reason and the ratio achieved through the postulates of logic. The source of Burhani's science is ratio, not text as it applies in the Bayani method, or intuition as it applies in the Irfani method. To gain science using the burhani method, one must adopt ways of drawing Aristotelian syllogistic conclusions, with several conditions, namely: 1) knowing the background of the preparation of the premise, 2) the existence of logical consistency between reason and conclusion, and 3) the conclusion drawn has to be certain and true, so it does not reveal other truths.

These are the three methods of thinking that developed in the Islamic scientific tradition since the early period, especially in interpreting the nash, as seen in the classification of the schools in the fields of figh, tafsir (interpretation) and kalam studies. These three epistemological categories also play a role in the development of science in next periods.

In general, the classification of science in the Islamic tradition is divided into two branches, namely: first, syar'iyyah science, a branch of science that relies more on texts or al-dalail alsyar'iyyah (naqliyah). Second, basyariyah science, or commonly known as insaniyah science which is based on the power of reason ("aqliyah). In the early period of the development of Islam, the two were never truly separated in the scientific tradition in Islam. At that time, the Quran and the Hadith were the only source of science in the literal understanding. ${ }^{39}$

At the conceptual level, what is meant by syar'iyah or naqliyah science is in line with the bayani epistemological paradigm, where texts (the Quran and Hadith) are the most authoritative sources in their application. The science of syar'iyah or the science of naqli is obtained or produced by thinking deeply (ijtihad) with certain methods and requirements. The first person to regulate the epistemology of bayani was Muhammad bin Idris al-Shafi'i (767-820), one of the initiators of the Islamic jurisprudence school. In its period, bayani was interpreted as something that contained the main problem (ushul) and that develops to the branch (furu').

In Shafi'i's view, the main (ushul) as a source of reconciliation in Islamic law is the Quran, Sunnah, and Qiyas, as well as Ijma'.40 In general, the epistemological structure of bayani figh animates almost all Islamic sciences. In the context of Islamic studies, especially aspects of naqliyah, science of figh and ushul figh is the culmination of science civilization, especially in the matter of searching for epistemology. ${ }^{41}$ In

39 Azyumardi Azra, Pendidikan Islam: Tradisi dan Modernisasi Menuju Milenium Baru (Jakarta: Logos, 2000), p. 13.

${ }^{40}$ Khudori Soleh, Wacana Baru Filsafat Islam (Yogyakarta: Pustaka Pelajar, 2004), p. 178.

${ }^{41}$ In the Islamic scientific realm, figh and usul figh occupy a special position, especially in the matter of the epistemological excavation of Islam. See a number of views on this subject on W.C. Smith, The Concept of Shari'a Among Some Mutakallimin, dalam George Abraham Makdisi (ed.) Arabic and Islamic Studies in Honor of Hamilton A.R. Gibb, (Leiden: E.J. Brill, 1965); Joseph 
addition, fiqh is a manifestation of the obedience form of servants to Allah SWT which contains all the commands and prohibitions regarding all aspects of human life, as illustrated in the scope of discussion such as worship, mu'amalat, ahwal syakhsiyah, ahkam sultaniyah, 'uqubat, adab and morals as well as siyar (laws concerning the rules of relations between an Islamic states and other countries). These historical facts and science developments show that figh justifies the plurality of legal epistemological formulations due to the role of different language games. ${ }^{42}$

If it is seen from the structure of bayani above, it appears that the Quran (revelation) in Islamic scientific traits is used as a paradigm. The paradigm is the construction of science that enables Muslims to understand reality as does the Quran. With this construction, Muslims then formulate the grand design of the entire Islamic system, and the developed science system. The manifestation of the Quran paradigm, according to Kontowijoyo, does not only stop at the axiological aspect, but also function as an epistemological framework. 43

In terms of the method of thinking, basyariyah or 'aqliyah is different from the science of syar'iyah or naqliyah. Naqliyah is more in line with the epistemology of burhani which is based on the power of reason and ratio. As explained above, the achievement of this episthemology model through the postulates of logic, and the source of science, is considered not from the text, but the ratio. In fact, in the view of positivism, basyariyah such as philosophy, biology, science and technology are always considered to be in conflict with the syar'iyah studies, because they are seen as promoting mystical thinking. However, it should be underlined, if it is observed from the development of science in Islamic history, especially in the era of science

Schacht, Theology and Law in Islam dalam G.E. von Grunebaum (ed.), Theology and Law Islam, (Weisbaden: Otto Harrasowitz, 1969), p. 23; Muhammad 'Abid al-Jabiri, Takwin al-'Aql al-'Araby, (Beirut: Markaz Dirasat al-Wahdah al-'Arabiyah, 1989), p. 23, 96.

42 Efrinaldi, "Ushul Fikih: Rekonstruksi Metodologis dalam Dinamika Hukum Islam," Jurnal Ilmiah Mizani, vol. 5, no. 2 (2018), p. 110.

43 Kuntowijoyo, Islam sebagai Ilmu, Epistemologi, Metodologi dan Etika, (Bandung: Teraju, 2004), p. 51. growth during the Abbasid dynasty in Baghdad and Umayyad dynasty II in Spain, there was no known dichotomy of science at that time. The great Islamic scientists in the fields of science in Baghdad and Spain have never built distance with the main sources of Islamic science, the Quran and the Sunnah. This fact can be read in the works of Islamic scientists in the field of science. The philosophical work adapted from the works of Greek philosophers which is entirely based on human logical reasoning, but in the hands of Islamic scientists, the translation made more sense because the peak of its integrity was based on monotheistic values extracted from the paradigm of the Quran. The medical science, art, astronomy and so forth, are always described in the integralistic paradigm, which puts forward the values of monotheism. For example, when discussing the anatomy of living things, Muslim scientists make all their creative efforts to get to know the majesty of Allah SWT as the creator. All empirical processes and symptoms that are absorbed and observed become a means to increase obedience and awe to Allah SWT.

The term science has experienced semantic reduction time by time. This term is taken from Latin scio, scire, scientia which means "I know", "know" and "science". There is no limit to what science is, by whom and in what way science is obtained. So what belongs to the category of science also needs to be limited to physics, biology, chemistry and its branches. Therefore, in the view of some Islamic scholars, the ways of interpreting the verses of the Quran with the help of science are still problematic, if it not unlawful, because they are judged to be able to experience dereliction and error. ${ }^{44}$ Science is humane (kasbi), thus al-Ghazali, it is obtained through the efforts. This kind of science never reaches the peak of certainty, but approaches.

Thus, from the perspective of science experience that has been developed in Islam, although 'aqli science is considered to prioritize the aspect ratio in terms of its epistemological side, but in reality it is always dialectic with its main sources, namely the Quran and Sunnah.

${ }^{44}$ Manna' al-Qattan, Mabahits fi 'Ulum al-Quran, (Riyadh: Manshurat al-‘Asr al-Hadits, 1973), p. 350-352. 


\section{Conclusion}

In the context of developing the integration of science, a number of universities have tried to implement the idea. However in the experience and dynamics developed by each university, the concepts, applications, opportunities and challenges, eventually produced different models and patterns of integration. However, if it is excluded, all of these institutions attempt to integrate integrative science with religion. The results of this study indicate that in the application of science integration in a number of Higher Education Institutions in Indonesia, it is implemented in different levels. At the conceptual level some have had a systematic concept. The majority of State Islamic Universities in Indonesia have a strong philosophical paradigm, by carrying out the concept of science integration. Whereas in the elaboration aspect of the integration paradigm, the curriculum has been applied.

The concept of integration of science was developed at the State Islamic University (UIN) in Indonesia which substantially actually refers to the mutual goal, namely the elimination of the dichotomy between the truth of revelation and the modern science. In this context, science integration really is trying to combine the truth of revelation and the truth of science implemented in Islamic higher education in Indonesia. However, the concept of science integration in each UIN in Indonesia has editorial diversity and elaboration that is particularly contextual with the respective environments.

\section{References}

Abdullah, M. Amin, "Religion, Science and Culture; An Integrated, Interconnected Paradigm of Science", Jurnal Al-Jami'ah, vol. 52, no. 1, $2014 \mathrm{M} / 1435 \mathrm{H}$.

Abdullah, M. Amin, Islamic Studies. Bandung: Pustaka Pelajar, 2006.

Al-Faruqi, Ismail Raji, Al-Tauhid: Its Implications for Thought and Life. Virginia-USA: The International Institute of Islamic Thought, 1992.

Arbi, et.al., Model Pengembangan Paradigma Integrasi Ilmu di Universitas Islam Negeri Sunan Kalijaga Yogyakarta dan Universitas
Islam Negeri Maulana Malik Ibrahim Malang, Jurnal Profetika, Jurnal Studi Islam, vol. 20, no. 1, Juni 2018.

Asiyah,“Epistemologi Keilmuan Baru di Perguruan Tinggi Keagamaan Islam Negeri (Transformadi dari STAIN/IAIN Menjadi UIN", Jurnal Madania, vol. 20, no. 2, Desember 2016.

Anas, Norazmi, et.al. "The Integration of Knowledge in Islam: Concept and Challenges," dalam Global Journal of Human Social Science, Vol. 13, 2013.

Baharun, Hasan. "Management Information Systems in Education: The Significance of e-Public Relation for Enhancing Competitiveness of Higher Education." Journal of Physics: Conference Series, 1175: 12151, IOP Publishing, 2019.

Barbour, Ian G., When Science Meets Religion, New York: Harper San-Fransisco, 2000.

Bungin, Burhan, Analisis Data Penelitian Kualitatif. Jakarta: Raja Grafindo Persada, 2003.

Darda, Abu, "Integrasi Ilmu dan Agama: Perkembangan Konseptual di Indonesia" in Jurnal At-Ta'dib, vol. 10, no. 1, Juni 2015.

Efrinaldi, "Ushul Fikih: Rekonstruksi Metodologis dalam Dinamika Hukum Islam," Jurnal Mizani, Wacana Hukum, Ekonomi, dan Keagamaan, vol. 5, no. 2, 2018.

, "Spektrum Fiqh Siyasah dan Dinamisasi Pemikiran Politik Islam di Indonesia, Jurnal Madania, vol. XVII, no. 1, Juni 2013.

Gall, Meredith Damien, Walter R Borg, and Joyce P Gall. Educational Research: An Introduction. Longman Publishing, 1996.

Hassan, Usman, The Concept of 'llm and Knowledge in Islam, The Association of Muslim Scientists and Engineers, 2003.

Jamal, Nur, Model-model Integrasi Keilmuan Perguruan tinggi Keagamaan Islam, Jurnal Kabilah, vol. 2, no.1, Juni 2017.

Junaidi, Mahfud, IImu Pendidikan Islam: Filsafat dan Pengembangan, Semarang: RaSAIL Media Group, 2010.

Nur, Saleh, "Muhammad Iqbal: Studi Pemikiran Filsafat dan Tasawuf", Jurnal Ushuluddin, vol. XV, no. 2, Juli 2009.

Qomar, Mujamil, Merintis Kejayaan Islam Kedua: Merombak Pemikiran dan Mengembangkan Aksi, Yogyakarta: Teras, 2012. 
Ramayulis dan Samsul Nizar, Ensiklopedi Tokoh Pendidikan Islam, Mengenal Tokoh Pendidikan Islam di Dunia Islam dan di Indonesia, Ciputat, Quantum Teaching: 2005.

Rifal, Nurlena, et.al, "Integrasi Keilmuan Dalam Pengembangan Kurikulum di UIN seIndonesia: Evaluasi Penerapan Inetgrasi Keilmuan UIN dalam Kurikulum dan Proses Pembelajaran," dalam Jurnal Tarbiya, vol. 1, no.1, Juni 2014.

Roswantoro, Alim, dalam M. Yusuf dan Mustofa (ed.), Mengukir Prestasi di Jalur Khusus, Yogyakarta: Depag RI, 2007.

Solichin, Mohammad Muchlis,"Islamisasi Ilmu Pengetahuan dan Aplikasinya dalam Pendidikan Islam," dalam Jurnal Tadris, vol. 3, no. 1, 2008.
S. Praja, Juhaya, Filsafat dan Metodologi IImu dalam Islam. Jakarta: Teraju, 2002.

Taufiqurrahman, et.al., "Pola Integrasi Keilmuan, Pengembangan Kajian Keislaman pada Lembaga Pendidikan Tinggi Islam di Kawasan Asia Tenggara", Laporan Riset Kompetitif, Kluster Penelitian Internasional, UIN Imam Bonjol Padang, 2017.

Titus, Harold H.,et.al, Persoalan-Persoalan Filsafat. Jakarta: Bulan Bintang, 1984.

Wan Daud, Wan Ramli bin, dan Shaharir, "Pemelayuan, Pemalaysiaan dan Pengislaman Ilmu Sains dan Teknologi dalam Konteks Dasar Sains Negara”, Jurnal Kesturi, no. 1. 1999.

Zein, Mas'ud, "Axiology on the Integration of Knowledge, Islam and Science," Jurnal AtTalim, vol. 21, no. 2, Juli 2014. 